\title{
Justification of the Nature of Fluctuations in Nigerian Bank Returns: an Empirical Analysis
}

Guobadia Emwinloghosa Kenneth ${ }^{1}$, $^{*}$

${ }^{1}$ Department of Administration, Federal Medical Centre, Asaba, Delta State, Nigeria

${ }^{2}$ Department of Statistics, University of Benin, Benin, Nigeria

DOI: $10.36347 /$ sjebm.2021.v08i01.002

| Received: 16.01.2021 | Accepted: 25.01.2021 | Published: 28.01.2021

*Corresponding author: Guobadia Emwinloghosa Kenneth

Abstract

Original Research Article

The study attempted to identify the most important factors that affect the investment returns of Nigerian banks 'shares in the financial market. By using statistical models and lag time variables (one year lag) to interpret the return on investment per share in the current year, it is concluded that there was no statistically significant effect of the following independent factors: capital adequacy, surpluses, cash, market value-added, liquidity ratio, and trading volume on return on investment for commercial bank shares. The study showed a statistically significant effect of the size of the assets and the tax rate on the return on investment of commercial banks' shares. Moreover, the independent factors explain $55 \%$ of the fluctuations that occur in the profitability of banks. The study recommends paying attention to intellectual capital (added market value). It was not statistically significant and important as a factor that reflects the extent of banking awareness among clients and the extent of their acceptance of banks' new banking services. This study is original and attempted to identify the most important factors that affect the investment returns of Nigerian banks 'shares in the financial market.

Keywords: Banks returns, investment returns, capital adequacy, surplus cash, market value added, liquidity ratio. Copyright $(\mathcal{C} 2021$ The Author(s): This is an open-access article distributed under the terms of the Creative Commons Attribution 4.0 International License (CC BY-NC 4.0) which permits unrestricted use, distribution, and reproduction in any medium for non-commercial use provided the original author and source are credited.

\section{INTRODUCTION}

The main pillar of the continuation and growth of any bank in light of the rapid developments is the creation of administrative and financial factors that affect the growth of investment returns. The primary goal is to maintain their survival and enhance their financial position, through the ability to achieve cash surpluses represented by the difference between the incoming cash inflows and outcoming cash flows. Some banks found that modern administration do not depend on returns on investment in the material sense only, but also on ideas or what is known as intellectual capital that creates loyalty among clients and investors in dealing with the bank. Here, it measures the bank's management efficiency in generating the owners' revolution and increasing profits from its total investments while maintaining reducing risks to lowest levels [1-6].

\section{OBJECTIVES OF THE STUDY}

It seeks to explain fluctuations in return on investment for shares of Nigerian banks listed on the
Amman Stock Exchange. To achieve this, the study tries to answer the following questions:

- Is the Amman Stock Exchange a fertile environment for achieving investment returns?

- How is this fertile environment measured - if any?

- Can the financial indicators that are the subject of the study explain the behavior of investment returns in stocks?

The importance of these questions come first, if the return on investment for the shares of banks on the Amman Stock Exchange is not determined randomly, then the bank's current financial indicators can be used to forecast future investment returns and second when we try to explain the behavior of investment returns for stocks, it facilitates knowing the climate and dealers of the financial market, and it has to set investment policies to achieve returns [7-12].

\section{RESEARCH HYPOTHESES}

There is no statistically significant effect of the study variables in explaining the behavior of fluctuations in bank profitability. The study population is represented by 15 Nigerian banks whose shares are 
Guobadia Emwinloghosa Kenneth., Sch J Econ Bus Manag, Jan, 2021; 8(1): 10-13

listed on the Amman Stock Exchange during the study period from 2003-2018, some of which were excluded due to insufficient data during the study period, so 11 commercial banks were approved, knowing that numbers were extracted study variables through the financial statements published on the Amman Stock
Exchange [13-16]. The study relied on the descriptiveanalytical approach, and since we use the variables of the past year to explain the return on investment per share in the current year (Lagged model) the number of observations per variable is eliminated by one. The proposed model is as follows:

$$
\text { Epst }=(\text { MVAt }-1)(A t-1)(C A t-1)(\mathrm{Lt}-1)(\mathrm{CS} \mathrm{t}-1)(\mathrm{T} \mathrm{t}-1)(\mathrm{VT} \mathrm{t}-1)
$$

Where:

The return on investment per share in the current year is the dependent variable of the study (EPs t). It can be calculated by dividing the net annual income by the number of ordinary shares issued, and this measure shows the performance of the company and the extent of its ability to invest its assets effectively, and the rise in this measure is a good indicator of the success and efficiency of management in investment projects and policies [17-19].

MVA t-1 is the market value added in the last year. This variable also expressed by the intellectual capital represented by the difference between the value of stock prices in the financial market and the book value in the company records, this measure shows the knowledge base and awareness in assessing the efficiency of management through the optimal use of resources and promoting the shareholders' rights. The market value of the stock price is measured by the product of the market price multiplied by the number of ordinary shares issued. The book value is expressed in the total shareholders' equity in the company's records [20-22].

The size of the company in the last year (A) includes the total money in the bank, knowing that most of this money is for others and the capital is often not more than $10 \%$ of its assets, and the total assets were approved to measure the size of the company. Moreover, the total assets produced and utilized by the administration in a proper manner would increase the returns on investment. Capital Adequacy in the past year (CA t-1) means being cautious and aware of the various risks that banks are exposed to from their operations. It is measured by dividing the total shareholders' equity by the total risky assets.

Dangerous assets are defined as all assets except liquid assets (cash, balances with the central bank, balances with banks and financial institutions). Examples of risky assets are loans with or without collateral and other securities (long-term investments).

( $\mathrm{L} \mathrm{t}-1)$ is also known as the circulation ratio, which shows the extent of the bank's ability to meet its short-term liabilities coverage through cubes and the size of its current assets. The index of this ratio varies according to the nature of the bank's policy, and this indicator was calculated as follows:
Cash on hand + balance at the Central Bank + balances with banks in the Kingdom at the main center or branches operating outside the kingdom + bills + bills due within three months

Deposits + other bank deposits + head office balances or branches operating outside the Kingdom + the uncovered part of the letters of guarantee (guarantees)

Cash surpluses (CS t-1) express the availability of investable cash. To exploit these surpluses, it is assumed that investment strategies that generate financial returns are adopted instead of remaining unexploited liquidity, calculated through the equation:

Cash surplus $=$ cash and cash equivalents at the end of the year / Total right of owners

The increase in taxes ( $\mathrm{T} \mathrm{t}-1)$ leads to greater erosion of the banks' profits, thereby reducing the returns on investment for stocks. The study predicts that the tax relationship with the return on investment will be negative.

Trading Volume (VT t-1) is the extent to which investors want to buy the bank's shares, and the increase in this variable is evidence of the extent of investors rushing towards shares that achieve capital gains.

\section{STUDY RESULT}

Table 1 shows a summary of the descriptive statistics of the independent variables and the dependent variable of the commercial banks, where the average, median, highest value, lowest value, median, and the standard deviation for each of the variables appear. The return rates on investment for the average and median were $(0.5599)$ and $(0.22)$ respectively reflecting that the Nigerian banks are achieving good profit rates. Moreover, for the added market value the average and the median were $(3.26 \mathrm{E}+08),(4.52 \mathrm{E}+07)$. However, we note that the size of the bank was on average $(3.10 \mathrm{E}$ $+09)$ and its median $(1.17 \mathrm{E}+09)$. As Table 1 shows the average capital adequacy $(0.17234)$ and its median (0.177) indicate that commercial banks maintain $17 \%$ of the weighted assets with risks, this is a good percentage compared to the rate imposed by the Central Bank of Nigeria, which is $(12 \%)$. Table 1 also shows that the average liquidity ratio and its median are (0.448909) and $(0.45)$, respectively. 
Guobadia Emwinloghosa Kenneth., Sch J Econ Bus Manag, Jan, 2021; 8(1): 10-13

Table-1: Shows descriptive statistics for independent variables and dependent variable

\begin{tabular}{|l|l|l|l|l|l|l|l|l|}
\hline & EPS & MVA & A & CA & L & CS & T & VT \\
\hline Mean & 0.559 & $3.26 \mathrm{E}+08$ & $3.10 \mathrm{E}+09$ & 0.17234 & 0.44890 & 2.2213 & 13093333 & $1.25 \mathrm{E}+08$ \\
\hline Median & 0.22 & $4.52 \mathrm{E}+07$ & $1.17 \mathrm{E}+09$ & 0.177 & 0.45 & 1.64 & $5.42 \mathrm{E}+06$ & $1.72 \mathrm{E}+07$ \\
\hline Max & 15.82 & $9.28 \mathrm{E}+09$ & $2.59 \mathrm{E}+10$ & 0.31604 & 0.89 & 12.86271 & $1.29 \mathrm{E}+08$ & $3.35 \mathrm{E}+09$ \\
\hline Min & -0.36 & $-9.80 \mathrm{E}+07$ & $6.68 \mathrm{E}+06$ & -0.39648 & 0.17 & -3.04944 & -2075411 & $1.17 \mathrm{E}+05$ \\
\hline Std. D & 2.053 & $1.08 \mathrm{E}+09$ & $5.66 \mathrm{E}+09$ & 0.07527 & 0.13237 & 2.12507 & 21215449 & $3.78 \mathrm{E}+08$ \\
\hline
\end{tabular}

The correlation matrix is used to show the relationship between independent and dependent variables on the one hand and between the independent variables among them, on the other, to ensure that there is no strong correlation between them, which indicates what is known as the double correlation between the two variables and the multiple between more than two variables which negatively affects the sincerity of the regression results. Table 2 indicates that the relationship between independent variables, between return on investment and assets is weak (0.3540). Moreover, between them and the added market value is less than $60 \%$, and it is also weak in the sense that there are no double or multiple correlations between the model's independent variables [23].

Table-2: The correlation matrix appears between the independent and dependent variables

\begin{tabular}{|l|l|l|l|l|l|l|l|l|}
\hline & EPS & MVA & A & CA & L & CS & T & VT \\
\hline EPS & 1 & & & & & & & \\
\hline MAV & 0.105399 & 1 & & & & & & \\
\hline A & 0.354061 & 0.6089142 & 1 & & & & & \\
\hline CA & -0.11761 & 0.1089549 & 0.12985 & 1 & & & & \\
\hline L & 0.046575 & 0.0431800 & -0.0352 & 0.14920 & 1 & & & \\
\hline CS & 0.081879 & -0.083510 & -0.1101 & -0.1781 & 0.58739 & 1 & & \\
\hline T & 0.149955 & 0.5734743 & 0.93048 & 0.18576 & -0.1056 & -0.184 & 1 & \\
\hline VT & 0.059701 & 0.2900692 & 0.5622 & 0.1314 & 0.03287 & 0.0931 & -0.5326 & 1 \\
\hline
\end{tabular}

\section{REGRESSION RESULTS}

The fixed-effects model, the random-effects model, and the Haussmann test were estimated. The Hausman test results indicated that the fixed effects model is appropriate for the factors affecting the returns on investment in commercial banks operating in Nigeria, where the probability of significance level was less than
$5 \%$. The results of the regression analysis are presented in Table 3. It shows that the minimum capital adequacy, cash surpluses, and the market value-added effect are negative on the return rate on investment. However, it is not statistically significant, their value reached ($2,210,1091),(0.050970))$, and $(-2.25 \mathrm{E}-10)$, respectively

Table-3: The effect of factors affecting returns on investment in commercial banks in Nigeria appears.

\begin{tabular}{|l|l|l|}
\hline Independent Variables & Dependent Variables \\
\hline & EPS Fixed effect Model & EPS Random effect Model \\
\hline A-1 & $7.59 \mathrm{E}-10(11.79354)^{* * *}$ & $6.58 \mathrm{E}-10(11.22165)^{* * *}$ \\
\hline CA-1 & $-2.291091(-1.361940)$ & $-1.951332(-1.203549)$ \\
\hline CS-1 & $-0.050970(-0.677692)$ & $-0.024540(-0.346447)$ \\
\hline L-1 & $0.571113(0.507166)$ & $0.058925(0.053677)$ \\
\hline MVA-1 & $-2.25 \mathrm{E}-10(-0.699039)$ & $-2.61 \mathrm{E}-10(-2.051274)^{* *}$ \\
\hline T-1 & $-1.43 \mathrm{E}-07(-8.877032)^{* * *}$ & $-1.33 \mathrm{E}-07(-8.786839)^{* * *}$ \\
\hline VT-1 & $1.94 \mathrm{E}-10(0.214332)$ & $-6.11 \mathrm{E}-10(-0.783316)$ \\
\hline Adjusted R-squared & 0.550250 & 0.410512 \\
\hline F-statistic & 12.80276 & 17.31533 \\
\hline Hausman test (Chi -Sq) & 36.383102 & \\
\hline Prob (Chi -Sq) & 0000 & \\
\hline NO & 165 & 165 \\
\hline Banks & 11 & 11 \\
\hline
\end{tabular}

Table 3 indicates that the effect of both the liquidity rate and the trading volume is positive on the rates of return on investment. However, they are not statistically significant, as their value reached $(0.571113)$ and $(10-94 \mathrm{E})$, respectively. Moreover, the results of the fixed effects model always indicate positive and statistically significant impact on the rate of return on investment for commercial banks operating in Nigeria, and this indicates that banks in Nigeria improve the optimization of operating and exploiting their assets in a manner that increases their profits. Moreover, the tax is always negative and statistically 
Guobadia Emwinloghosa Kenneth., Sch J Econ Bus Manag, Jan, 2021; 8(1): 10-13

significant in its impact on the rate of return on investment for commercial banks, where it reached (1.43E-07), and this result is logical because the taxes are expended and their rise is a burden that leads to high deductions and the resultant erosion of profits. Adjusted $\mathrm{R}$-squared states that $55 \%$ of the independent factors explain the changes in return rates on investment in the commercial banks operating in Nigeria.

\section{CONCLUSION AND RECOMMENDATIONS}

The results of the analysis show that the relationship of the independent factors, capital adequacy, cash surpluses, added market value, liquidity ratio, and trading volume correspond to the assumptions of the study, whereas the result related to the size of the assets and the tax rate does not correspond to the assumptions of the study. The independent factors explain $55 \%$ of the changes in the return rates on investment in the commercial banks operating in Nigeria. The study recommends paying attention to intellectual capital (added market value) although it was not statistically significant and important as a factor that reflects the extent of banking awareness among clients and the extent of their acceptance of new banking services.

\section{REFERENCE}

1. Khlat M, Ronsmans C. Deaths attributable to childbearing in Matlab, Bangladesh: indirect causes of maternal mortality questioned. American Journal of Epidemiology. 2000 Feb 1;151(3):300-6.

2. Conde-Agudelo A, Belizán JM, Lammers C. Maternal-perinatal morbidity and mortality associated with adolescent pregnancy in Latin America: Cross-sectional study. American journal of obstetrics and gynecology. 2005 Feb 1;192(2):342-9.

3. Maxwell O, Happiness OI, Alice UC, Chinedu IU. An empirical assessment of the impact of Nigerian all share index, Market Capitalization, and Number of Equities on Gross Domestic Product. Open Journal of Statistics. 2018 May 9;8(3):584-602.

4. Maxwell O, Chukwudike CN, Chinedu OV, Valentine $\mathrm{CO}$ and Paul O. Comparison of different Parametric Estimation Techniques in Handing Critical Multicollinearity: Monte Carlo Simulation Study. Asian Journal of Probability and Statistics. 2019; 3(2), 1-16.

5. Morgan KJ and Eastwood JG. Social determinants of maternal self- rated health in South Western Sydney, Australia. BMC Research Notes. 2014; 7(1), 1-12.

6. Haddad LB and Nour NM. Unsafe abortion: unnecessary maternal mortality. Reviews in obstetrics and gynecology. 2009; 2(2), 122.

7. Fertility Regulation and Reproductive Health in the Millennium Development Goals: The search for a perfect indicator
8. Lee ET and Wang JW. Statistical Methods for Survival Data Analysis. 3rd ed. New Jersey: John Wiley \& Sons. 2003.

9. Guobadia Emwinloghosa Kenneth, Obubu Maxwell and Sharon Chinyere Amechi. COVID-19 Outbreak: An Asthmatic Asymptomatic Case Report. Journal of Applied Medical Sciences. 2020; 9(2): 29-34

10. Gehan EA. Estimating Survival functions from the life table. Journal of chronic diseases. 1969; 21: 629-644. http://www.sciepub.com/reference/1055

11. Greenwood M. "The natural duration of cancer". Reports on Public Health and Medical subjects, (London: Her Majesty's Stationary Office). 1926; 33: $1-26$.

12. Gehan EA. Estimating survival functions from the life table. Journal of chronic diseases. 1969 Feb 1;21(9-10):629-44.

13. Lee ET, Wang J. Statistical methods for survival data analysis. John Wiley \& Sons; 2003 Aug 1.

14. Osuji GA, Obubu M, Nwosu CA. Stock investment decision in Nigeria; A PC Approach. World. 2016 Jan;2(1).

15. Osuji GA, Okoro CN, Obubu M, Obiora-Ilouno HO. Effect of akaike information criterion on model selection in analyzing auto-crash variables. Int J Sci Basic Appl Res. 2016;26(1):98-109.

16. Pet R, Pet J. Asymptotically efficient rank invariant procedure. JR Stat.:185-206.

17. Cox DR. Regression Models and Life Tables," Journal of the Royal Statistical Society. Scr. B, 34. 187-202.(1975). Partial Likelihood," Biometrika. 1972;62:269-76.

18. Obubu M, Konwe CS, Nwabenu DC, Omokri PA, Chijioke M. Evaluation of the contribution of Nigerian stock market on economic growth; Regression approach. European Journal of Statistics and Probability. 2016 Oct;4(5):11-27.

19. Guobadia Emwinloghosa Kenneth. Statistical Application of Regression techniques in Modeling Road Accidents in Edo State, Nigeria. Sch J Phys Math Stat, 2021 Jan 8(1): 14-18

20. Nelson W. Theory and applications of hazard plotting for censored failure data. Technometrics. 1972 Nov 1;14(4):945-66.

21. Ekhosuehi N, Kenneth GE, Kevin UK. The Weibull Length Biased Exponential Distribution: Statistical Properties and Applications. Journal of Statistical and Econometric Methods. 2020;9(4):15-30.

22. Kenneth GE, Maxwell O, Amechi SC. COVID-19 Outbreak: An Asthmatic Asymptomatic. Journal of Applied Medical Sciences. 2020;9(2):29-34.

23. Osuji GA, Obubu M, Obiora-Ilouno HO. Uterine fibroid on women's fertility and pregnancy outcome in Delta State, Nigeria. Journal of Natural Sciences Research. 2016;6(2):27-33. 